\title{
Characterization of Defaulters from Tuberculosis Treatment in a Tertiary Hospital in South Eastern Nigeria
}

\author{
Echendu Dolly Adinma, Victor Ahoma Mbanuzuru, Emmanuel C. Azuike*, \\ Ifeoma C. Iloghalu, Darlington Chukwudimma Obi \\ Department of Community Medicine, Nnamdi Azikiwe University Teaching Hospital (NAUTH), Nnewi, Nigeria \\ Email: "emmanazuike@yahoo.com
}

Received 26 September 2015; accepted 4 December 2015; published 7 December 2015

Copyright (C) 2016 by authors and Scientific Research Publishing Inc.

This work is licensed under the Creative Commons Attribution International License (CC BY).

http://creativecommons.org/licenses/by/4.0/

c) (7) Open Access

\section{Abstract}

Background: Tuberculosis is second only to HIV/AIDS as the greatest killer worldwide, due to a single infectious agent. Directly Observed Treatment Short-Course (DOTS) is presently the WHO recommended programme to fight tuberculosis worldwide. There is a need to understand the characteristics of patients who default from treatment for tuberculosis. This will help modify the strategies to reduce such default to the barest minimum and achieve higher levels of adherence. Objective: The aim of this study was to describe the characteristics of patients that defaulted from treatment for TB at Nnamdi Azikiwe University Teaching Hospital (NAUTH) Nnewi DOTS clinic for the period 1st January 2011 to 31st December 2012. Materials and Methods: This was a retrospective study conducted at the DOTS clinic at Nnamdi Azikiwe University Teaching Hospital Nnewi, Anambra State, Nigeria. The records of patients who received treatment from the clinic from 1st January 2011 to 31st December 2012 (2 years) were reviewed. The data collected include patients' demographic characteristics, treatment category, patient type, baseline sputum smear result, and retroviral status. From the data, default rate was calculated and its relationship with other variables noted. Associations between patients' characteristics were determined using chi square test of independence. The significance level was set at $\boldsymbol{p}=\mathbf{0 . 0 5}$. Results: A total of 765 patients enrolled for TB treatment in the DOTS clinic of the study area within the study period of 1 st January 2011 and December $31^{\text {st }}$ 2012. The mean age at commencement of the treatment was 33.14 years $( \pm 18.09)$. The outcome of treatment showed that $260(34 \%)$ had treatment completed, 230 (30.1\%) cured, 120 (15.7\%) defaulted, 103 (13.5\%) died, 40 (5.2\%) were transferred-out, and 12 $(1.6 \%)$ failed in the treatment, giving a treatment success rate of $64.1 \%$. Among the $120(15.7 \%)$ patients that defaulted from treatment, majority $80(66.7 \%)$ were males, and most $30(25.0 \%)$ were in the 30 - 39 years age group. Conclusion: Defaulting starts with treatment interruption hence prompt management of interruption of treatment and default will largely help in prevent-

${ }^{*}$ Corresponding author.

How to cite this paper: Adinma, E.D., Mbanuzuru, V.A., Azuike, E.C., Iloghalu, I.C. and Obi, D.C. (2016) Characterization of Defaulters from Tuberculosis Treatment in a Tertiary Hospital in South Eastern Nigeria. Open Journal of Epidemiology, 6, 1-9. http://dx.doi.org/10.4236/ojepi.2016.61001 
ing drug-resistant $\mathrm{TB}$.

Keywords

Tuberculosis, Treatment Defaulters, Tertiary Hospital, South Eastern Nigeria

\section{Introduction}

Tuberculosis (TB) is an infectious disease caused by Mycobacterium tuberculosis, and occasionally Mycobacterium bovis or Mycobacterium africanum. It affects mainly the lungs, leading to Pulmonary TB. It could also affect other sites of the body (extra-pulmonary TB). The extra-pulmonary sites include: gastrointestinal tract, mainly the ileocaecal area, but occasionally the peritoneum, producing ascites; the central nervous system, causing tuberculosis meningitis and tuberculomas; the genitourinary system, affecting the kidneys, epididymis, fallopian tubes, leading to infertility in some females; the skeletal system causing septic arthritis and osteomyelitis; the skin giving rise to lupus vulgaris; the eyes where it can cause choroiditis or iridocyclitis; the pericardium causing constrictive pericardititis; the adrenal glands producing Addison's disease; and lymph nodes, especially in young adults and children, with hilar and para-tracheal lymph nodes being mostly affected. The affected nodes are initially firm and discreet but later they become matted and may even suppurate with sinus formation [1] [2].

TB remains one of the world's deadliest communicable diseases. It was estimated that in 2013, 9 million people developed TB, and approximately 1.5 million died from the disease. TB is present in all regions of the world [1]. Nigeria is one of the 22 high burden countries (HBCs), accounting for $80 \%$ of world's TB cases, and the 3rd among the six countries with largest number of incident cases after India and China. According to World Health Organization latest report, the prevalence of TB in Nigeria is 326 per 100,000 population, while the incidence is 338 per 100,000 population [1]. For effective management of TB, WHO recommended Directly Observed Treatment Short-Course (DOTS) policy in 1990. The Nigerian National Tuberculosis and Leprosy Control Programme (NTBLCP) adopted this DOTS strategy in 1993 [2].

The treatment of TB depends on the case definition before the commencement. New cases are treated with category 1 regimen, while retreatment of relapses, failures, return-after-default and others require category 2 regimen. The category 1 regimen involves treatment for 6 months' duration, with initial 2 months intensive phase using fixed dose combination (FDC) of four drugs (Isoniazid, Rifampicin, Pyrazinamide and Ethambutol), and then 4 months of continuation phase using Isoniazid and Rifampicin; but if Ethambutol and Isoniazid are used then it will last for 6 months [3]-[6]. The retreatment regimen (category 2) consists of Rifampicin, Isoniazid, Pyrazinamide, Ethambutol and Streptomycin in the intensive phase. The Strepomycin is discontinued at the end of 2 months, while Rifampicin, Isoniazid, Pyrazinamide and Ethambutol are continued for additional one month to cover the 3 months of the intensive phase. The continuation phase uses Rifampicin, Isoniazid and Ethambutol, which are given for 5 months to cover the entire 8 months period of retreatment [2] [6].

Treatment outcome of TB could be [3]: Cured-smear positive at diagnosis, who completed treatment with smear-negative at the end of 6th or 7th month of treatment and at least one previous occasion; Treatment completed—smear negative or extrapulmonary patient who completed treatment; Treatment failure—patient remains or becomes smear positive again at the end of 5th month or later during treatment; Died-patient who died for any reason during the course of the treatment; Defaulter-any patient who has interrupted for 8 consecutive weeks or more after the date of the last attendance during the course of the treatment; Transferred-out-patient who was transferred to another treatment centre in another state and whose treatment result was not known.

The emergence of resistance to drugs used to treat tuberculosis and particularly multi-drug resistant tuberculosis (MDR-TB) is significant problem and poses obstacle to effective TB control at both national and global levels. Resistance arises at various levels in the management of a patient, ranging from poor compliance, inadequate supervision, inadequate dosing, drug combinations, duration of treatment and poor training of staff [3] [4]. Drug-resistant TB can be prevented largely through effective implementation of basic DOTS policy through: uninterrupted supply of good quality anti-TB drugs for the full duration of the treatment, provision of adequate patient education throughout the course of treatment to ensure adherence to treatment, prompt management of 
interruption of treatment and default, provision of anti-TB drugs in compliance with National Guidelines, free anti-TB services to the patients [4] [5]. Treatment compliance of every patient is absolutely essential in order to cure the patient and prevent drug-resistant tuberculosis. Health workers should do all in their power to ensure that patients complete treatment in the required time (adherence).

This study elicited information on the characteristics of patients that defaulted in the course of TB treatment.

\section{Methodology}

\subsection{Study Area}

The study was conducted in the Nnamdi Azikiwe University Teaching Hospital (NAUTH), Nnewi, Anambra State, Nigeria. NAUTH is a tertiary, referral hospital located near the major business areas of south-eastern Nigeria. It serves Anambra, Imo, Delta, Enugu and Abia States of Nigeria. It is a renowned Teaching Hospital in Nigeria which runs daily DOTS clinic in addition to other clinical departments. It is also a training centre for both undergraduates and post-graduates medical students, as well as other allied medical workers.

\subsection{Study Design}

It was a Retrospective study utilizing analysis of data abstracted from the treatment register of the DOTS clinic from 1st January 2011 to 31st December 2012. The data collected include patients' demographic characteristics, treatment category, patient type, baseline sputum smear result, retroviral status. From the data, default rate was calculated and its relationship with other variables noted.

\subsection{Data Collection}

Data was collected from the Tuberculosis clinic register. The clinic is otherwise called Directly Observed Treatment Short-Course (DOTS) clinic. A proforma was used to extract the required information about the patients.

\subsection{Data Analysis}

The data was analysed using Statistical Package for Social Sciences (SPSS) version 20. Chi-square test was used to determine the relationship between variables. A p-value of $\leq 0.05$ was considered statistically significant. Ethical clearance for the study was obtained from the NAUTH Ethical Committee. The results were presented in figure and tables.

\section{Results}

A total of 765 patients enrolled for TB treatment in the DOTS clinic of the study area within the study period of 1st January 2011 and December 31st 2012. Figure 1 shows that the mean age at commencement of the treatment was 33.14 years, with a standard deviation of 18.09.

Table 1 shows the distribution of patients by demographic characteristics, type of TB, TB/HIV status, types of patient, treatment category, and outcome of TB treatment. Majority of the patients, 445 (58.2\%), were males. More than eighty one percent of the cases were less than 50 years old while only $7 \%$ were greater than 60 years old. Majority of the patients, 634 (82.9\%) resided outside Nnewi town. Most of the patients, 662 (86.5\%), had pulmonary TB, while 103 (13.5\%) had extra-pulmonary type of TB. The baseline sputum smear microscopy result, before the commencement of the treatment, shows that 346 (45.2\%) of the patients had positive sputum AFB, 283 (37.0\%) had negative sputum AFB, while 136 (17.8\%) could not produce sputum. Retroviral status of the patients shows that majority of the patients, 496 (61.3\%) had negative retroviral status at the commencement of the treatment, while 296 (38.7\%) had HIV/TB co-infection. Types of patient indicate that majority, 618 (80.8\%) were new cases; 21 (2.7\%) relapsed cases; 7 (0.9\%) failure cases; and 18 (2.4\%) were return after default (RAD) cases. Of the 765 patients, 626 (81.6\%) were treated with Category 1 Regimen, while the rest, 139 (18.2\%) were treated with Category 2 Regimen. The outcome of treatment shows that 260 (34\%) had treatment completed, 230 (30.1\%) cured, 120 (15.7\%) defaulted, 103 (13.5\%) died, 40 (5.2\%) were transferred-out, and 12 (1.6\%) failed in the treatment, giving a treatment success rate of $64.1 \%$. 
Table 1. Distribution of patients by demographic characteristics, type of TB, treatment category, patient type, TB/HIV status, and outcome of TB treatment.

\begin{tabular}{|c|c|c|}
\hline Characteristics & Frequency & Percentage \\
\hline \multicolumn{3}{|l|}{ Sex } \\
\hline Male & 445 & 58.2 \\
\hline Female & 320 & 41.8 \\
\hline Total & 765 & 100 \\
\hline \multicolumn{3}{|l|}{ Age (years) } \\
\hline$<20$ & 173 & 22.6 \\
\hline $20-29$ & 143 & 18.7 \\
\hline $30-39$ & 170 & 22.2 \\
\hline $40-49$ & 137 & 17.9 \\
\hline $50-59$ & 86 & 11.2 \\
\hline$\geq 60$ & 56 & 7.3 \\
\hline Total & 765 & 100 \\
\hline \multicolumn{3}{|l|}{ Residence } \\
\hline Within Nnewi & 131 & 17.1 \\
\hline Outside Nnewi & 634 & 82.9 \\
\hline Total & 765 & 100 \\
\hline \multicolumn{3}{|l|}{ Disease site } \\
\hline Pulmonary & 662 & 86.5 \\
\hline Extra-pulmonary & 103 & 13.5 \\
\hline Total & 765 & 100 \\
\hline \multicolumn{3}{|l|}{ Category of treatment } \\
\hline Cat 1 & 626 & 81.6 \\
\hline Cat 2 & 139 & 18.2 \\
\hline Total & 765 & 100 \\
\hline \multicolumn{3}{|l|}{ First sputum result } \\
\hline Positive & 346 & 45.2 \\
\hline Negative & 283 & 37.0 \\
\hline Cannot produce & 136 & 17.8 \\
\hline Total & 765 & 100 \\
\hline \multicolumn{3}{|l|}{ Type of patient } \\
\hline New case & 618 & 80.8 \\
\hline Relapse & 21 & 2.7 \\
\hline Failure & 7 & 0.9 \\
\hline Return after default (RAD) & 18 & 2.4 \\
\hline
\end{tabular}




\begin{tabular}{lcc} 
Continued & & \\
\hline Transfer in & 13 & 1.7 \\
Others & 88 & 11.5 \\
Total & $\mathbf{7 6 5}$ & $\mathbf{1 0 0}$ \\
Baseline HIV status & & 38.7 \\
Positive & 296 & 61.3 \\
Negative & 469 & 30.1 \\
Outcome of treatment (result) & & 34.0 \\
Cured & 230 & 1.6 \\
Treatment completed & 260 & 13.5 \\
Failure & 12 & 15.7 \\
Died & 103 & 5.2 \\
Defaulted & 120 & $\mathbf{1 0 0}$ \\
Transferred out & 40 & $\mathbf{1 0}$ \\
Total & $\mathbf{7 6 5}$ & \\
\hline
\end{tabular}

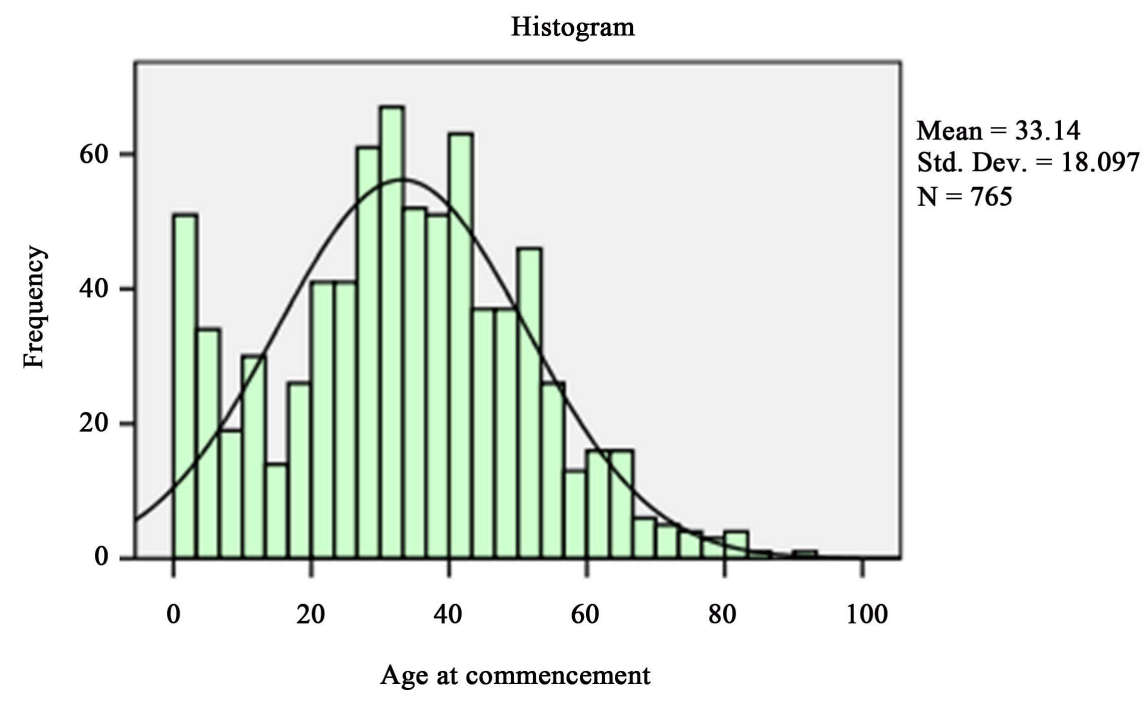

Figure 1. Age distribution at commencement of treatment (years).

The distribution of the association between patients' gender and age for TB treatment outcome is shown in Table 2. Among the 120 (15.7\%) patients that defaulted from treatment, majority 80 (66.7\%) were males, and most 30 (25.0\%) were in the 30 - 39 years age group.

Table 3 shows the distribution of the association between patients' place of residence and TB treatment outcome. Patients who were residing outside the study area, Nnewi, 108 (90.0\%) defaulted from TB treatment more than those who were resident in Nnewi, 12 (10.0\%).

There were more TB defaulters, 98 (81.7\%), among those on treatment Category 1 Regimen than those in treatment Category 2 Regimen, 22 (18.3\%), as shown in Table 4.

Table 5 shows the distribution of the association between patients' baseline sputum AFB result and TB treatment outcome. Fifty (17.7\%) of patients who tested negative to the AFB screening defaulted from TB treatment, as against the $15.0 \%$ of those who were AFB positive that defaulted from treatment. 
Table 2. Distribution of the association between patients TB treatment outcome and some characteristics (sex and age).

\begin{tabular}{|c|c|c|c|c|c|c|c|}
\hline & Cured & $\begin{array}{l}\text { Treatment } \\
\text { completed }\end{array}$ & Failure & Died & Default & $\begin{array}{c}\text { Transferred } \\
\text { out }\end{array}$ & Total \\
\hline $\begin{array}{l}\text { Sex } \\
\text { Male } \\
\text { (\%) }\end{array}$ & $\begin{array}{c}126 \\
(54.8 \%)\end{array}$ & $\begin{array}{c}155 \\
(59.6 \%)\end{array}$ & $\begin{array}{c}11 \\
(91.7 \%)\end{array}$ & $\begin{array}{c}50 \\
(48.5 \%)\end{array}$ & $\begin{array}{c}80 \\
(66.7 \%)\end{array}$ & $\begin{array}{c}23 \\
(57.5 \%)\end{array}$ & $\begin{array}{c}445 \\
(58.2 \%)\end{array}$ \\
\hline $\begin{array}{l}\text { Female } \\
(\%)\end{array}$ & $\begin{array}{c}104 \\
(45.2 \%)\end{array}$ & $\begin{array}{c}105 \\
(40.4 \%)\end{array}$ & $\begin{array}{c}1 \\
(8.3 \%)\end{array}$ & $\begin{array}{c}53 \\
(51.5 \%)\end{array}$ & $\begin{array}{c}40 \\
(33.3 \%)\end{array}$ & $\begin{array}{c}17 \\
(42.5 \%)\end{array}$ & $\begin{array}{c}320 \\
(41.8 \%)\end{array}$ \\
\hline $\begin{array}{l}\text { Total } \\
\text { (\%) }\end{array}$ & $\begin{array}{c}230 \\
(100 \%)\end{array}$ & $\begin{array}{c}260 \\
(100 \%)\end{array}$ & $\begin{array}{c}12 \\
(100 \%)\end{array}$ & $\begin{array}{c}103 \\
(100 \%)\end{array}$ & $\begin{array}{c}120 \\
(100 \%)\end{array}$ & $\begin{array}{c}40 \\
(100 \%)\end{array}$ & $\begin{array}{c}765 \\
(100 \%) \\
\{\boldsymbol{p}=\mathbf{0 . 1 4}\}\end{array}$ \\
\hline \multicolumn{8}{|c|}{ Age (years) } \\
\hline $\begin{array}{l}<20 \\
(\%)\end{array}$ & $\begin{array}{c}20 \\
(8.7 \%)\end{array}$ & $\begin{array}{c}94 \\
(36.2)\end{array}$ & $\begin{array}{c}3 \\
(25.0 \%)\end{array}$ & $\begin{array}{c}21 \\
(20.4)\end{array}$ & $\begin{array}{c}29 \\
(24.2 \%)\end{array}$ & $\begin{array}{c}6 \\
(15.0 \%)\end{array}$ & $\begin{array}{c}173 \\
(22.6 \%)\end{array}$ \\
\hline $\begin{array}{l}20-29 \\
(\%)\end{array}$ & $\begin{array}{c}70 \\
(30.4 \%)\end{array}$ & $\begin{array}{c}34 \\
(13.1 \%)\end{array}$ & $\begin{array}{c}3 \\
(25.0 \%)\end{array}$ & $\begin{array}{c}10 \\
(9.7 \%)\end{array}$ & $\begin{array}{c}17 \\
(14.2 \%)\end{array}$ & $\begin{array}{c}9 \\
(22.5 \%)\end{array}$ & $\begin{array}{c}143 \\
(18.7 \%)\end{array}$ \\
\hline $\begin{array}{l}30-39 \\
(\%)\end{array}$ & $\begin{array}{c}62 \\
(27.0 \%)\end{array}$ & $\begin{array}{c}48 \\
(18.5 \%)\end{array}$ & $\begin{array}{c}1 \\
(8.3 \%)\end{array}$ & $\begin{array}{c}20 \\
(19.4 \%)\end{array}$ & $\begin{array}{c}30 \\
(25.0 \%)\end{array}$ & $\begin{array}{c}9 \\
(22.5 \%)\end{array}$ & $\begin{array}{c}170 \\
(22.2 \%)\end{array}$ \\
\hline $\begin{array}{l}40-49 \\
(\%)\end{array}$ & $\begin{array}{c}43 \\
(18.7 \%)\end{array}$ & $\begin{array}{c}41 \\
(15.8 \%)\end{array}$ & $\begin{array}{c}3 \\
(25.0 \%)\end{array}$ & $\begin{array}{c}21 \\
(20.4 \%)\end{array}$ & $\begin{array}{c}23 \\
(19.2 \%)\end{array}$ & $\begin{array}{c}6 \\
(15.0 \%)\end{array}$ & $\begin{array}{c}137 \\
(17.9 \%)\end{array}$ \\
\hline $\begin{array}{l}50-59 \\
(\%)\end{array}$ & $\begin{array}{c}23 \\
(10.0 \%)\end{array}$ & $\begin{array}{c}27 \\
(10.4 \%)\end{array}$ & $\begin{array}{c}1 \\
(8.3 \%)\end{array}$ & $\begin{array}{c}18 \\
(17.5 \%)\end{array}$ & $\begin{array}{c}8 \\
(6.7 \%)\end{array}$ & $\begin{array}{c}9 \\
(22.5 \%)\end{array}$ & $\begin{array}{c}86 \\
(11.2 \%)\end{array}$ \\
\hline $\begin{array}{l}\geq 60 \\
(\%)\end{array}$ & $\begin{array}{c}12 \\
(5.2 \%)\end{array}$ & $\begin{array}{c}16 \\
(6.2 \%)\end{array}$ & $\begin{array}{c}1 \\
(8.3 \%)\end{array}$ & $\begin{array}{c}13 \\
(12.6 \%)\end{array}$ & $\begin{array}{c}13 \\
(10.8 \%)\end{array}$ & $\begin{array}{c}1 \\
(2.5 \%)\end{array}$ & $\begin{array}{c}56 \\
(7.3 \%)\end{array}$ \\
\hline Total (\%) & $\begin{array}{c}230 \\
(100)\end{array}$ & $\begin{array}{c}260 \\
(100)\end{array}$ & $\begin{array}{c}12 \\
(100)\end{array}$ & $\begin{array}{c}103 \\
(100)\end{array}$ & $\begin{array}{c}120 \\
(100)\end{array}$ & $\begin{array}{c}40 \\
(100)\end{array}$ & $\begin{array}{c}765 \\
(100)\end{array}$ \\
\hline & & & & & & & $\{p=0.000\}$ \\
\hline
\end{tabular}

Table 3. Distribution of the association between patients' place of residence and TB treatment outcome.

\begin{tabular}{cccccccc}
\hline & Cured & $\begin{array}{c}\text { Treatment } \\
\text { completed }\end{array}$ & Failure & Died & Default & $\begin{array}{c}\text { Transferred } \\
\text { out }\end{array}$ & Total \\
\hline $\begin{array}{c}\text { Residence } \\
\text { location }\end{array}$ & & & & & & & \\
Within Nnewi & 44 & 52 & 2 & 17 & 12 & 4 & 131 \\
(\%) & $19.1 \%$ & $20 \%$ & $16.7 \%$ & $16.5 \%$ & $10 \%$ & $10 \%$ & $17.1 \%$ \\
$\begin{array}{c}\text { Outside Nnewi } \\
\text { (\%) }\end{array}$ & 186 & 208 & 10 & 86 & 108 & 36 & 634 \\
Total (\%) & $80.9 \%$ & $80 \%$ & $83.3 \%$ & $83.5 \%$ & $90 \%$ & $90 \%$ & $82.9 \%$ \\
& $230(100)$ & $260(100)$ & $12(100)$ & $103(100)$ & $120(100)$ & $40(100)$ & $765(100)$ \\
$\{\boldsymbol{p}=\mathbf{0 . 1 6 1 \}}$ \\
\hline
\end{tabular}

Table 4. Distribution of the association between patients' category of treatment and treatment outcome.

\begin{tabular}{cccccccc}
\hline $\begin{array}{c}\text { Category of } \\
\text { treatment }\end{array}$ & Cured & $\begin{array}{c}\text { Treatment } \\
\text { completed }\end{array}$ & Failure & Died & Default & $\begin{array}{c}\text { Transferred } \\
\text { out }\end{array}$ & Total \\
\hline CAT 1 & 207 & 193 & 8 & 89 & 98 & 31 & 626 \\
$(\%)$ & $90 \%$ & $74.2 \%$ & $66.7 \%$ & $86.4 \%$ & $81.7 \%$ & $77.5 \%$ & $81.8 \%$ \\
CAT 2 & 23 & 67 & 4 & 14 & 22 & 9 & 139 \\
$(\%)$ & $10 \%$ & $25.8 \%$ & $33.3 \%$ & $13.6 \%$ & $18.3 \%$ & $22.5 \%$ & $18.2 \%$ \\
Total (\%) & $230(100)$ & $260(100)$ & $12(100)$ & $103(100)$ & $120(100)$ & $40(100)$ & $765(100)$ \\
& & & & & & & $\mathbf{p}=\mathbf{0 . 0 0 0}$ \\
\hline
\end{tabular}

Majority, 97 (80.8\%), of the patients who defaulted from treatment were new cases of TB, as shown in Table 6. However, Table 7 shows that most of the defaulters, 77 (64.2\%), were HIV negative. 
Table 5. Distribution of the association between patients' initial sputum AFB result and TB treatment outcome.

\begin{tabular}{|c|c|c|c|c|c|c|c|}
\hline First sputum result & Cured & $\begin{array}{l}\text { Treatment } \\
\text { completed }\end{array}$ & Failure & Died & Default & $\begin{array}{c}\text { Transferred } \\
\text { out }\end{array}$ & Total \\
\hline Positive & $\begin{array}{c}227 \\
65.6 \%\end{array}$ & $\begin{array}{c}7 \\
2.0 \%\end{array}$ & $\begin{array}{c}10 \\
2.9 \%\end{array}$ & $\begin{array}{c}30 \\
8.7 \%\end{array}$ & $\begin{array}{c}52 \\
15.0 \%\end{array}$ & $\begin{array}{c}20 \\
5.8 \%\end{array}$ & $\begin{array}{c}346 \\
100 \%\end{array}$ \\
\hline Negative & $\begin{array}{c}2 \\
0.7 \%\end{array}$ & $\begin{array}{c}166 \\
58.7 \%\end{array}$ & $\begin{array}{c}1 \\
0.4 \%\end{array}$ & $\begin{array}{c}50 \\
17.7 \%\end{array}$ & $\begin{array}{c}50 \\
17.7 \%\end{array}$ & $\begin{array}{c}14 \\
4.9 \%\end{array}$ & $\begin{array}{c}283 \\
100 \%\end{array}$ \\
\hline Can’t produce & $\begin{array}{c}1 \\
0.7 \%\end{array}$ & $\begin{array}{c}87 \\
64.0 \%\end{array}$ & $\begin{array}{c}1 \\
0.7 \%\end{array}$ & $\begin{array}{c}23 \\
16.9 \%\end{array}$ & $\begin{array}{c}18 \\
13.2 \%\end{array}$ & $\begin{array}{c}6 \\
4.4 \%\end{array}$ & $\begin{array}{c}136 \\
100 \%\end{array}$ \\
\hline Total (\%) & 230 & 260 & 12 & 103 & 120 & 40 & $\begin{array}{c}765 \\
\{\boldsymbol{p}=\mathbf{0 . 0 0 0}\}\end{array}$ \\
\hline
\end{tabular}

Table 6. Distribution of the association between type of patient and TB treatment outcome.

\begin{tabular}{|c|c|c|c|c|c|c|c|}
\hline Type of patient & Cured & $\begin{array}{l}\text { Treatment } \\
\text { completed }\end{array}$ & Failure & Died & Default & $\begin{array}{c}\text { Transferred } \\
\text { out }\end{array}$ & Total \\
\hline New case & $\begin{array}{c}206 \\
89.6 \%\end{array}$ & $\begin{array}{c}189 \\
72.7 \%\end{array}$ & $\begin{array}{c}8 \\
66.7 \%\end{array}$ & $\begin{array}{c}87 \\
84.5 \%\end{array}$ & $\begin{array}{c}97 \\
80.8 \%\end{array}$ & $\begin{array}{c}31 \\
77.5 \%\end{array}$ & $\begin{array}{c}618 \\
80.8 \%\end{array}$ \\
\hline Relapse & $\begin{array}{c}9 \\
3.9 \%\end{array}$ & $\begin{array}{c}2 \\
0.8 \%\end{array}$ & $\begin{array}{c}1 \\
8.3 \%\end{array}$ & $\begin{array}{c}6 \\
5.8 \%\end{array}$ & $\begin{array}{c}1 \\
0.8 \%\end{array}$ & $\begin{array}{c}2 \\
5 \%\end{array}$ & $\begin{array}{c}21 \\
2.7 \%\end{array}$ \\
\hline Failure & $\begin{array}{c}4 \\
1.7 \%\end{array}$ & $\begin{array}{c}0 \\
0.0 \%\end{array}$ & $\begin{array}{c}0 \\
0.0 \%\end{array}$ & $\begin{array}{c}0 \\
0.0 \%\end{array}$ & $\begin{array}{c}3 \\
2.5 \%\end{array}$ & $\begin{array}{c}0 \\
0.0 \%\end{array}$ & $\begin{array}{c}7 \\
0.9 \%\end{array}$ \\
\hline $\mathrm{RAD}$ & $\begin{array}{c}8 \\
3.5 \%\end{array}$ & $\begin{array}{c}1 \\
0.4 \%\end{array}$ & $\begin{array}{c}2 \\
16.7 \%\end{array}$ & $\begin{array}{c}0 \\
0.0 \%\end{array}$ & $\begin{array}{c}5 \\
4.2 \%\end{array}$ & $\begin{array}{c}2 \\
5 \%\end{array}$ & $\begin{array}{c}18 \\
2.4 \%\end{array}$ \\
\hline Transfer-in & $\begin{array}{c}3 \\
1.3 \%\end{array}$ & $\begin{array}{c}5 \\
1.9 \%\end{array}$ & $\begin{array}{c}0 \\
0.0 \%\end{array}$ & $\begin{array}{c}3 \\
2.9 \%\end{array}$ & $\begin{array}{c}1 \\
0.8 \%\end{array}$ & $\begin{array}{c}1 \\
2.5 \%\end{array}$ & $\begin{array}{c}13 \\
1.7 \%\end{array}$ \\
\hline Others & $\begin{array}{c}0 \\
0.0 \%\end{array}$ & $\begin{array}{c}63 \\
24.2 \%\end{array}$ & $\begin{array}{c}1 \\
8.3 \%\end{array}$ & $\begin{array}{c}7 \\
6.8 \%\end{array}$ & $\begin{array}{c}13 \\
10.8 \%\end{array}$ & $\begin{array}{c}4 \\
10 \%\end{array}$ & $\begin{array}{c}88 \\
11.5 \%\end{array}$ \\
\hline Total (\%) & $230(100)$ & $260(100)$ & $12(100)$ & 103(100) & $120(100)$ & $40(100)$ & $\begin{array}{c}765(100) \\
\{\boldsymbol{p}=\mathbf{0 . 0 0 0}\}\end{array}$ \\
\hline
\end{tabular}

Table 7. Distribution of the association between patients’ HIV status and TB treatment outcome.

\begin{tabular}{|c|c|c|c|c|c|c|c|}
\hline HIV status & Cured & $\begin{array}{l}\text { Treatment } \\
\text { completed }\end{array}$ & Failure & Died & Default & $\begin{array}{c}\text { Transferred } \\
\text { out }\end{array}$ & Total \\
\hline Positive & $\begin{array}{c}58 \\
25.2 \%\end{array}$ & $\begin{array}{c}104 \\
40 \%\end{array}$ & $\begin{array}{c}4 \\
33.3 \%\end{array}$ & $\begin{array}{c}72 \\
69.9 \%\end{array}$ & $\begin{array}{c}43 \\
35.8 \%\end{array}$ & $\begin{array}{c}15 \\
37.5 \%\end{array}$ & $\begin{array}{c}296 \\
38.7 \%\end{array}$ \\
\hline Negative & $\begin{array}{c}172 \\
74.8 \%\end{array}$ & $\begin{array}{l}156 \\
60 \%\end{array}$ & $\begin{array}{c}8 \\
66.7 \%\end{array}$ & $\begin{array}{c}31 \\
30.1 \%\end{array}$ & $\begin{array}{c}77 \\
64.2 \%\end{array}$ & $\begin{array}{c}25 \\
62.5 \%\end{array}$ & $\begin{array}{c}469 \\
61.3 \%\end{array}$ \\
\hline Total (\%) & $230(100)$ & $260(100)$ & 12 (100) & 103 (100) & $120(100)$ & 40 (100) & $\begin{array}{c}765(100) \\
\{\boldsymbol{p}=\mathbf{0 . 0 0 0}\}\end{array}$ \\
\hline
\end{tabular}

\section{Discussion}

Defaulting from TB treatment is one of the factors that slow the progress of meeting the target of WHO TB treatment success rate of $85 \%$. Treatment compliance of every TB patient is therefore absolutely essential in order to cure patients, as well as prevent drug-resistant tuberculosis. This study elicited information on the characteristics of TB patients who defaulted from treatment.

The mean age of the patients was $33.14 \pm 18.1$ years, with 486 (63.5\%) patients being less than 40 years old. Those aged less than 20 years account for $22.6 \%$. This supports the fact that TB affects mostly people in the reproductive age group [1] [7]-[11]. However, a similar study in Switzerland reported a mean age of $62.5 \pm 19.3$ years [12].

Greater percentage of the patients (58.2\%) are males. This is similar to the global report and other studies [1] [7] [10] [11] [13] [14]. It is worthy of note that though majority of the patients came from outside the study area, yet the association between residence and treatment outcome was not statistically significant $(p=0.161)$. Probably this may be because all the patients in our study came from the same country (tribe). Studies done in Swit- 
zerland and Malaysia showed significant difference between indigenous cases and that of the foreigners [12] [15].

Out of 765 patients studied, 626 (81.8\%) were treated with category 1 regimen, and the rest with category 2. Most, 618 (80.8\%), of the patients were enrolled as "New Cases" and were treated with category 1 regimen. The remaining percentage of patients treated with Cat 1 regimen would have come from the "Transfer-in" group. Belete et al. showed similar percentage of "New Cases" in a study on treatment outcome of tuberculosis patients under directly observed treatment in Addis Ababa, Ethiopia [8]. More than 86\% of the patients in this study had pulmonary tuberculosis, which is in tandem with other similar studies [10]. Omotosho et al. [7] in a similar study in Owo, South-Western Nigeria, reported a higher figure of $94.8 \%$, similar to $97 \%$ reported by Atif et al. in a study in Malaysia [15].

In this study, $45.2 \%$ patients had positive sputum microscopy, $37 \%$ had negative smear while $17.8 \%$ could not produce sputum. Four hundred and ninety-six of the patients $(61.3 \%)$ were retroviral negative, while $38.7 \%$ were TB/HIV co-infected. This is higher than the $22 \%$ TB/HIV co-infection for the entire country and also $34 \%$ for the African region reported by WHO Global report [1]. This figure is less than the $45.3 \%$ reported by the study from south-western Nigeria [7]. This is probably because this study was conducted in a referral centre, like that from South-western Nigeria. The study in Nairobi by Bernard et al. gave HIV co-mobidity as a predictive factor for default [10]. Though the DOTS clinic and HIV clinic are in the same centre, yet each clinic is run separately with patients receiving different appointment dates. This will increase the transport and opportunity costs [10]. A close and complex association exists between tuberculosis and HIV, with TB as leading cause of death in people with HIV [6].

The treatment success rate (cured and treatment completed) in this study is $67.6 \%$ among the smear positive cases. This is below the recommended target of $85 \%$ set by World Health Organization [1] [3] and also cure rate of 75.5\% reported by Omotosho [7] as well as the treatment success rate of 86\% reported nationally in 2012 [1].

The default rate of $15.7 \%$ from this study is comparable to $18.3 \%$ reported by Karanjekar et al. [13], but greater than 3\% and 8.93\% reported by Omotosho et al. [7] and Atif et al. [15] respectively. Among the 120 patients that defaulted, $43.3 \%$ had positive smear, while $41.7 \%$ were negative. In addition, majority of the defaulters, $80.8 \%$, were new cases and were treated with TB Category 1 regimen. One-quarter of the defaulters were in the age group 30 - 39 years, with more males, $66.7 \%$, than females, 33.3\%, defaulting from TB treatment. This finding is in tandem with other studies which had reported similar higher default rate among males [7] [13].

The limitation of this study, being conducted as a retrospective survey, is the inability to elicit the views of the patients on treatment interruption and defaulting in general. Muture et al. in their study had stated that patients' knowledge and beliefs about their illness, motivation to manage it and consequences of poor adherence interact to influence adherence behavior [10]. Further studies are needed to ascertain from patients why they default from TB treatment, and the ways to reduce it to the barest minimum.

\section{Conclusion/Recommendations}

Defaulting starts with treatment interruption hence prompt management of interruption of treatment and default will largely help in preventing drug-resistant TB. This calls for more effective patient education, supervision and support. There is also a need to maintain uninterrupted supply of good quality anti-tuberculosis drugs for the full duration of the treatment.

\section{References}

[1] WHO. Global Tuberculosis Report 2014.

[2] WHO. Global Tuberculosis Report 2013.

[3] Federal Ministry of Health. Department of Public Health (2010) National Tuberculosis and Leprosy Control Programme (NTBLCP). Worker's Manual. Revised 5th Edition, 11-63.

[4] Park, K. (2007) Park’s Textbook of Preventive and Social Medicine. 19th Edition, M/s Banarsidas Bhanot Publishers, Jabalpur, 149-166.

[5] Sunder, L.A.P. (2011) Textbook of Community Medicine-Preventive and Social Medicine. 3rd Edition, CBS Publishers \& Distributors, New Delhi, 420-431.

[6] Obionu, C.N. (2007) Primary Health Care for Developing Countries. 2nd Edition, Ezu Books, Enugu, 139-150. 
[7] Omotosho, B.A., Adebayo, A.M., Adeniyi, B.O., et al. (2014) Tuberculosis Treatment Outcomes and Interruption among Patients Assessing DOTS Regimen in a Tertiary Hospital in a Semi-Urban Area of South-Western Nigeria. Nigerian Journal of Medicine, 23, 51-56.

[8] Getahun, B., Ameni, G., Medhin, G. and Biadgilign, S. (2013) Treatment Outcome of Tuberculosis Patients under Directly Observed Treatment in Addis Ababa, Ethiopia. Brazilian Journal of Infectious Diseases, 17, 521-528. http://dx.doi.org/10.1016/j.bjid.2012.12.010

[9] Marx, F.M., Dunbar, R., Enarson, D.A. and Beyers, N. (2013) The Rate of Sputum Smear-Positive Tuberculosis after Treatment Default in a High-Burden Setting: A Retrospective Cohort Study. PLoS ONE, 8, e45724. http://dx.doi.org/10.1371/annotation/ea5f2a13-4394-41af-84c8-3e6af4a07770

[10] Muture, B.N., Keraka, M.N., Kimuu, P.K., Kabiru, E.W., Ombeka, V.O. and Oguya, F. (2011) Factors Associated with Default from Treatment among Tuberculosis Patients in Nairobi Province Kenya: A Case Control Study. BMC Public Health, 11, 696. http://dx.doi.org/10.1186/1471-2458-11-696

[11] Epco, H., Maksad, K., Shakhnoz, U., Umid, A., Umida, Y., van der Werf Marieke, J., Gulnoz, U. and Jaap, V. (2008) Default from Tuberculosis Treatment in Tashkent, Uzbekistan; Who Are These Defaulters and Why Do They Default. BMC Infectious Diseases, 8, 97. http://dx.doi.org/10.1186/1471-2334-8-97

[12] Kherad, O., Herrmann, F.R., Zellweger, J.P., Rochat, T. and Janssens, J.P. (2009) Clinical Presentation, Demographics and Outcome of Tuberculosis (TB) in a Low Incidence Area: A 4-Year Study in Geneva, Switzerland. BMC Infectious Diseases, 9, 217. http://dx.doi.org/10.1186/1471-2334-9-217

[13] Karanjekar, V.D., Lokare, P.O., Gaikwad, A.V., Doibale, M.K., Gujrathi, V.V. and Kulkarni, A.P. (2014) Treatment Outcome and Follow-Up of Tuberculosis Patients Put on Directly Observed Treatment Short-Course under Rural Health Training Center, Paithan, Aurangabad in India. Annals of Medical and Health Sciences Research, 4, 222-226. http://dx.doi.org/10.4103/2141-9248.129047

[14] Chennaveerappa, P.K., Jayashree, N., Nareshkumar, M.N., Praveen, G., Halesha, B.R. and Vinaykumar, M.V. (2014) TB-DOTS Outcome in Relation to HIV Status: Experience in a Medical College. Journal of Clinical and Diagnostic Research, 8, 74-76.

[15] Atif, M., Sulaiman, S.A., Shafie, A.A., Ali, I., Asif, M. and Babar, Z.U. (2014) Treatment Outcome of New Smear Positive Pulmonary Tuberculosis Patients in Penang, Malaysia. BMC Infectious Diseases, 14, 399. http://dx.doi.org/10.1186/1471-2334-14-399

\section{List of Abbreviations}

AIDS: Acquired Immuno Deficiency Virus

DOTS: Directly Observed Treatment Short-Course

FDC: Fixed Dose Combination

HBC: High Burden Countries

HIV: Human Immuno deficiency Virus

NAUTH: Nnamdi Azikiwe University Teaching Hospital

NTBLCP: National Tuberculosis and Leprosy Control Program

WHO: World Health Organisation 